\title{
Antisipasi Degradasi Moral di Era Global
}

\author{
Sofa Muthohar \\ IAIN Walisongo Semarang \\ Email: sofamuthohar@yahoo.co.id
}

\begin{abstract}
In the globalization era, environment has a broad definition. Someone could very easily find an atmosphere that he likes. It brings to positive or negative effects. Teenagers (aged 12-22 years) are the generation most vulnerable to the negative influences that lead to moral decadence. This problem is very difficult to overcome if it just rely on the secular West psychological theories. Islamic education is expected to provide a solution to these problems through functional strategy, integral and progressive. Religious teachings not only memorized but should also be presented in the spirit to assist young people in solving the problem. This strategy could be: guiding problem solving in dealing with problems themselves and society as well as the formation of an integral understanding of his relationship with God. Teens should have spirit that can transform itself into a superior person.
\end{abstract}

Keywords: moral degradation, teens, globalization, progressive Islamic education integral functional.

\begin{abstract}
Abstrak
Dalam era globalisasi, lingkungan memiliki definisi yang luas. Seseorang bisa sangat mudah menemukan suasana yang dia suka sehingga memunculkan efek positif atau negatif. Remaja merupakan generasi yang paling rentan terhadap pengaruh negatif yang menyebabkan dekadensi moral. Masalah ini sangat sulit diatasi jika hanya mengandalkan teori-teori psikologi Barat yang sekuler. Pendidikan Islam diharapkan mampu memberikan solusi masalah ini melalui strategi yang fungsional, integral dan progresif. Ajaran agama tidak hanya dihafal tetapi juga harus dihadirkan dalam jiwa untuk mendampingi kaum muda dalam menyelesaikan masalahnya. Strategi ini bisa berupa: pembimbingan problem solving dalam menghadapi persoalan diri dan masyarakatnya serta pembentukan pemahaman secara integral tentang hubungannya dengan Allah. Remaja harus memiliki mental yang dapat merubah dirinya menjadi pribadi yang unggul.
\end{abstract}

Kata kunci: Degradasi moral, remaja, globalisasi, pendidikan Islam fungsional, integral, dan progresif. 


\section{A. Pendahuluan}

Moralitas sebagai bentuk kesepakatan masyarakat mengenai apa yang layak dan apa yang tidak layak dilakukan, mempunyai sistem hukum sendiri. Hampir semua lapisan masyarakat mempunyai suatu tatanan masing-masing, bahkan komunitas terkecil masyarakat kadang mempunyai moral/etika tersendiri dengan sistemnya sendiri. Tidak jarang hukuman bagi mereka yang melanggar moralitas, lebih kejam daripada hukuman yang dijatuhkan oleh institusi formal. Hukuman terberat dari seorang yang melanggar moralitas adalah beban psikologis yang terus menghantui, pengucilan dan pembatasan dari kehidupan yang 'normal'.

Masing-masing masyarakat mempunyai istilah yang beragam dalam membahasakan moral ini, ada yang menyebutnya dengan etika dan dalam Islam dikenal dengan akhlak. Dalam komunitas profesional dikenal dengan kode etik, sedangkan di tengah masyarakat sering dibahasakan dengan sopan santun, keseluruhannya mempunyai kesamaan yaitu apa yang patut dan apa yang tidak patut dilakukan oleh anggotanya.

Di tengah arus globalisasi, lingkungan pendidikan remaja,kini tidak lagi monoton dan terbatas di dalam lingkungan sekolah atau lembaga pendidikan. Anak bisa jadi berada di dalam lingkungan sekolah, namun kini dia punya akses untuk berhubungan, melihat langsung dan bisa jadi terlibat dalam kehidupan lain di dunia lain dengan media teknologi dan informasi. Kini lingkungan pendidikan mempunyai definisi yang lebih luas yaitu bukan hanya di mana siswa/anak itu tinggal, namun mencakup juga di mana anak itu menemukan dirinya sebagai seorang yang berarti. Anak dengan mudahnya menemukan tempat, suasana dan lingkungan yang berbeda dan kemudian mengidentifikasi menjadi suatu keadaan yang cocok atau tidak cocok untuk dirinya.

Dengan berbagai pengaruh lingkungan yang berbeda-beda ini, membuka peluang yang sangat lebar bagi seorang remaja untuk mempunyai kepribadian ganda (split personality) karena terjadinya gangguan pada masa remaja (childhood disorder)yang kalau dibiarkan terus-menerus dapat berakibat pada kejahatan remaja (juvenile delinquency). ${ }^{1}$

${ }^{1}$ Kartini Kartono, Patologi Sosial 2, Kenakalan Remaja, (Jakarta: Raja Grafindo Persada, 2013), hlm. 3-5. 
Di tengah keterbukaan inilah pentingnya penguatan kepribadian yang bermoral pada diri anak berbasis agama, karena sekarang ini moralitas yang dipilih juga akan mempengaruhi kekuatan pengaruhnya pada diri seseorang, yang dapat berakibat pada kekuatan prinsip dirinya untuk bisa memilih dan memilah serta memutuskan yang baik dan tidak baik, yang pantas dan yang tidak pantas bagi dirinya. Jangan sampai terjadi, merasa sudah membekali moralitas pada remaja, namun keliru dengan moralitas yang hampa karena ditegakkan dari nilai-nilai spiritual. Di sinilah peran penting pendidikan agama Islam yang integral dan fungsional dalam mengantisipasi degradasi moral remaja di era global.

\section{B. Labilitas Kepribadian Remaja}

Remaja (adolescence) berlangsung antara usia 12-21 tahun bagi wanita dan 13-22 tahun bagi laki-laki, ${ }^{2}$ menjadi satu generasi yang paling rawan terhadap pengaruh negatif, walaupun sangat berpotensi untuk bisa diarahkan kepada hal yang positif karena ditinjau dari sisi fisik dan psikisnya(psikopisik) sedang dalam tahap perubahan yang sangat menonjol dari anak-anak menuju dewasa. ${ }^{3}$ Para pakar psikologi rata-rata memandang masa remaja sebagai masa yang penting yang sangat mempengaruhi perjalanan hidup seseorang.

Sigmund Freud misalnya memandang masa remaja sebagai masa mencari hidup seksual yang mempunyai bentuk definitif; Spranger menyebutnya sebagai suatu masa pertumbuhan dengan perubahan struktur kejiwaan yang fundamental tentang kesadaran akan 'aku' yang berpengaruh terhadap berbagai segi kehidupan; Hoffman memandang masa remaja sebagai masa pembentukan

\footnotetext{
${ }^{2}$ Kalau dibagi antara remaja awal dengan dengan remaja akhir batasnya adalah usia 17/18 tahun, Lihat Muhammad Al-Mighwar, Psikologi Remaja, Petunjuk Bagi Guru dan Orang Tua, (Bandung: Pustaka Sia, 2011), hlm. 62. Maka usia 17 tahun sering menjadi tonggak dan ukuan seseorang remaja dianggap mulai memasuki masa kedewasaan karena masuk periode remaja akhir dengan mulainya penataan pola pikir dan mulai dianggap siap untuk mengemban beban-beban sosial orang dewasa. http://aurabianglala.blogspot.com/2012/12/periode-emas-dan-kritis-pada-anak.html, diakses $\operatorname{tgl} 17 / 10 / 2013$.

${ }^{3}$ Achmad Juntika Nurihsan dan Mubiar Agustin, Dinamika Perkembangan Anak \& Remaja, Tinjauan Psikologi, Pendidikan, dan Bimbingan, (Bandung: Refika Aditama, 2013), hlm.68.
} 
sikap-sikap terhadap segala sesuatu yang dialami individu; sedangkan Conger dan Erikson menyebut masa remaja sebagai masa yang amat kritis yang mungkin dapat menjadi the best of time and the worst of time. Kalau seorang remaja mampu mengatasi berbagai tuntutan secara integratif maka ia akan menemukan identitasnya yang akan dibawa menjelang masa dewasanya, namun sebaliknya jika ia gagal, maka ia akan berada pada krisis identitas (identity crisis) yang berkepanjangan. ${ }^{4}$

Secara tradisional, masa remaja dianggap sebagai periode badai dan tekanan (strum and drang atau storm and stress), suatu masa yang ditandai dengan ketegangan emosi yang tinggi secara internal sebagai akibat dari perubahan fisik dan kelenjar yang secara eksternal karena adanya tekanan sosial dalam menghadapi kondisi lingkungan yang baru akibat dari kurang mempersiapkan diri dalam menghadapi keadaan dan lingkungan baru tersebut. Tidak semua orang menghadapi badai dan tekanan dalam masa remajanya namun mayoritas menghadapinya dengan ketidakstabilan emosi dalam usahanya menyesuaikan diri dengan pola prilaku baru dan harapan sosial yang baru. ${ }^{5}$

Suatu hal yang harus diwaspadai khususnya pada masa remaja awal yaitu adanya perasaan ambivalensi antara keinginan bebas dari dominasi pengaruh orang tua sekaligus kebutuhan bimbingan dan bantuan dari orang tuanya. ${ }^{6} \mathrm{Hal}$ ini muncul akibat dari adanya keharusan dalam diri remaja untuk menyesuaikan diri sosial terutama dengan lawan jenis dan menyesuaikan diri dengan orang dewasa di luar lingkungan keluarga dan sekolah.

Perasaan ambivalensi ini bisa sangat membahayakan jika remaja terpengaruh pergaulan orang dewasa atau remaja yang dianggapnya lebih dewasa daripadanya yang mempunyai kecenderungan nakal. Maka dia bisa menggunakan kekuatan dan kekayaan orang tuanya untuk menopang keinginannya dalam menyesuaikan diri dan eksis dengan kelompoknya. Banyak orang tua yang tidak habis pikir tiba-tiba anaknya mempunyai keinginan dan kebutuhan yang melonjak besarnya atau keluar dari kebiasaan. Inilah posisi

\footnotetext{
${ }^{4}$ Nurihsan dan Agustin, Dinamika Perkembangan Anak ..., hlm. 68-69.

5 Nurihsan dan Agustin, Dinamika Perkembangan Anak ..., hlm.78, lihat juga http://hukum.unmuhjember.ac.id/in-dex.php/13-berita/11kenakalan-remaja, diakses tgl.17/10/2013.

${ }^{6}$ Zakiah Daradjat, Ilmu Jiwa Agama, (Jakarta: Penerbit Bulan Bintang, 1979), hlm. 108.
} 
puncak kelabilan remaja, kalau tidak diarahkan dan dibimbing dalam keadaan remaja seperti ini maka remaja akan terjerumus dalam kejahatan remaja (juvenile delinquency), namun sebaliknya jika mampu mendapatkan bimbingan dan diarahkan oleh orang yang tepat, maka akan bisa monorehkan prestasi puncaknya pada masa emas di remajanya (golden age adolescence).

\section{Ancaman Degradasi Moral Remaja Di Era Global}

Konsep dan standar baik buruk, patas dan tidak pantas telah berkembang sangat pesat sejajar dengan semakin majunya proses industrialisasi dan urbanisasi yang ditopang dengan cepatnya perkembangan teknologi informasi. Kesemuanya itu menjadi kesatuan yang tak terpisahkan dalam arus globalisasi. Globalisasi hanyalah ujung yang nampak, permukaan gunung es dalam samudera yang menyembul, namun di bawahnya terdapat sesuatu yang jauh lebih rumit dan besar, lebih berpengaruh dalam berbagai sisi kehidupan masyarakat, tergabung dalam arus besar industrialisasi dan kapitalisasi.

Semua masyarakat modern, terutama sekali di negara Barat, secara universal terkondisi menonjolkan Prestasi individual. Setiap orang didorong untuk mendapatkan sukses materiil. Akan tetapi masyarakat tidak selalu bisa menyediakan sarana dan fasilitas yang sama bagi setiap orang guna mencapai sukses materiil ini. Dalam mengejar kesuksesan ini menjadikan orang-orang bergerak di tengah struktur masyarakat yang terpecah-pecah, yang kemudian berubah menjadi kelompok atomistis (mikro) yang sangat mobil sifatnya. Dalam situasi demikian banyak orang yang mengalami depersonalisasi, di sisi lain kontrol sosial dan tradisi banyak kehilangan pengaruhnya. Sebaliknya, nafsu manusia modern untuk berkompetisi guna mencapai sukses materiil semakin menanjak, persaingan semakin sengit. Kondisi demikian jelas bisa memberikan tekanan batin pada setiap anggota masyarakat,banyak orang mengalami kekecewaan dan frustasi. ${ }^{7}$ termasuk di dalamnya para remaja.

1. Faktor-faktor Global Penyebab Degradasi Moral

Jika dipilah, maka ancaman globalisai terhadap degradasi moral remajaantara lain dalam keadaan:

\footnotetext{
${ }^{7}$ Kartono, Patologi Sosial ..., hlm. 85.
} 
a. Tersebar luasnya pandangan materialistis tanpa spiritualitas, ukuran kesuksesan lebih di ukur pada kesuksesan materiil dan mengenyampingkan moralitas.

b. Konsep moralitas kesopanan menjadi longgar karena terpengaruh budaya barat akibat dari mudahnya mencari informasi melalui ICT.

c. Budaya global menawarkan kenikmatan semu melalui $3 \mathrm{~F}$ : food, fashion dan fun.

d. Tingkat persaingan semakin tinggi, karena terbukanya sekat lokal dan kebanyakan bersifat online.

e. Masyarakat lebih bersifat individualistis dan kurang peduli dengan lingkungannya, sehingga kontrol moral terutama pada remaja menjadi rendah.

f. Keluarga kurang dapat memberi pengarahan, karena masing-masing orang tua sudah mempunyai kesibukannya sendiri atau bahkan broken home.

g. Sebagian besar sekolah tidak sepenuhnya dapat mengontrol perilaku siswa, karena keterbatasan waktu, sumber daya dan sumber dana ataupun kurang menekankan pentingnya moralitas.

Atau ringkasnya dalam bahasa Kartini Kartono pengaruh lingkungan yang buruk, ditambah dengan kontrol diri dan kontrol sosial yang semakin melemah dapat mempercepat munculnya kenakalan remaja ${ }^{8}$ ataupun degradasi moral remaja.

2. Bentuk-bentuk Penyelewengan Moral Remaja

Penyimpangan, degradasi, kenakalan atau bahkan kejahatan remaja selalu berlangsung dalam konteks antar personal dan sosio kultural. Kenakalan remaja dari sisi jenisnya setidaknya dapat dibagi menjadi empat macamyaitu:

a. Individual, kenakalan yang secara personal atau individualnya dengan ciri khas jahat (tidak normal) yang disebabkan oleh predisposisi dan kecenderungan penyimpangan prilaku yang diperkuat dengan stimuli sosial dan kondisi kultural

\footnotetext{
${ }^{8}$ Kartono, Patologi Sosial ..., hlm.78.
} 
b. Situasional, kenakalan yang dilakukan oleh anak normal, namun mereka banyak dipengaruhi oleh berbagai kekuatan situasional, stimuli sosial dan tekanan lingkungan yang 'menekan dan memaksa'.

c. Sistematis, kenakalan yang disistematisir dalam bentuk suatu organisasi struktural yaitu 'gang'. Kumpulan tingkah laku tersebut disertai pengaturan, status formal, peranan tertentu, nilai-nilai rite-rite, dan juga kebanggan, bahkan tidak jarang mereka menghasilkan bahasa-bahasa khas. ${ }^{9}$

d. Kumulatif, kenakalan yang terus menerus dilakukan sehingga bersifat kumulatif, ditiru diberbagai tempat dan menyebar luas di tengah masyarakat dan bisa mengakibatkan disintegrasi sosial. $^{10}$ Kumulatif bisa bersifat individu ataupun kelompok, pada tingkat akumulasi yang tinggi anak sudah sulit kembali pada prilaku yang sesuai dengan norma sosial yang ada. ${ }^{11}$

Adapun dari sisi bentuknya, setidaknya bisa dalam berbagai bentuk antara lain:

a. Kenakalan yang menimbulkan korban fisik pada orang lain: perkelahian, perkosaan, perampokan,pembunuhan, dan lain-lain.

b. Kenakalan yang menimbulkan korban materi: perusakan, pencurian, pencopetan, pemerasan, dan lain-lain.

c. Kenakalan sosial yang tidak menimbulkan korban di pihak orang lain: pelacuran, penyalahgunaan obat.

d. Kenakalan yang melawan status, misalnya mengingkari status anak sebagai pelajar dengan cara membolos, mengingkari status orang tua dengan cara minggat dari rumah atau membantah perintah mereka

e. Kenakalan remaja non-kriminal, yang mengalami masalah jenis ini cenderung tertarik pada kesenangan-kesenangan yang sifatnya menyendiri, apatis terhadap kegiatan

${ }^{9}$ Tentang korelasi komunitas, budaya dan kemunculan bahasa, lihat Heddy Shri Ahimsa-Putra, Strukturalisme Levi-Strauss, Mitos dan Karya Sastra, (Yogyakarta: Galang Press, 2001), hlm. 23-39.

${ }^{10}$ Kartono, Patologi Sosial ..., hlm.37 -46.

${ }^{11}$ Suyanto, dan Djihad Hisyam, Refleksi dan Reformasi Pendidikan di Indonesia Memasuki Milenium III, (Yogyakarta: Adicita Karya Nusa, 2000), hlm. 192. 
masyarakat atau sekolah. Remaja ini suka mengasingkan diri, menghindarkan diri dari kegiatan yang menumbuhkan kontak dengan orang lain. Perasaannya sangat peka dan mudah terluka, cepat tersinggung dan membesar-besarkan kekurangannya sendiri, dengan gejala umum sering menyendiri, melamun, apatis tidak bergairah, sangat mudah tersinggung, sangat mudah panik, sangat mudah bingung sehingga cenderung menjadi peminum, pemabuk, penghisap candu, narkotika, menjadi morfinis dan sebagainya, bahkan tega untuk bunuh diri. ${ }^{12}$

Karena pegaruh modernisasi dan globalisasi maka terjadi pergeseran batas kesopanan dan moralitas, dari yang dulunya tidak pantas menjadi biasa-biasa, dari yang dulunya sangat tidak mungkin dibayangkan menjadi kenyataan dan lain-lain. Khususnya dalam perilaku heteroseksual remaja, al-Migwar mencatat adanya berbagai perubahan di antaranya:

a. Perkembangan heteroseksual remaja kini cenderung lebih cepat daripada remaja tradisional. Berciuman saat berpacaran yang dianggap tabu pada remaja tradisional dianggap biasa saja pada remaja sekarang.

b. Waktu berkencan, cenderung lebih cepat dan berlanjut pada hubungan yang tetap, atau cepat berganti.

c. Pola pergaulan, remaja dulu bersifat lugu namun kini lebih mempunyai banyak alasan untuk mengikuti pola prilaku seksual yang baru karena meyakini bahwa itu merupakan keharusan atau orang lain juga melakukannya.

d. Remaja yang hamil di luar nikah dulu dianggap suatu aib yang besar dan dihukum orang tuanya dan diasingkan, kini seringkali diterima oleh orang tuanya, dinikahkan bahkan terkadang orang tua mereka ikut membesarkan dan menanggung biaya anak itu.

e. Hubungan seks, remaja dulu menganggap suatu yang tabu dan menimbulkan rasa bersalah, kini sebagian sudah menganggap biasa bahkan ada yang beranggapan bahwa orang yang saling mencintai sudah sewajarnya melakukan itu dengan didasari kasih sayang.

\footnotetext{
${ }^{12} \mathrm{http} / / /$ hukum.unmuhjember.ac.id/index.php/13-berita/11-kenakalanremaja, diakses tgl.17/10/2013.
} 
f. Keperawanan, asalnya dianggap suatu yang sangat sakral dan penting dalam perkawinan, kini sebagian menganggapnya kurang penting yang lebih penting adalah kesetiaan. ${ }^{13}$

Suatu pergeseran yang sangat mengerikan jika ditinjau dari sisi norma agama, namun dianggap biasa dari sisi norma sosial. Pergeseran norma sosial ini juga berlaku pada normanorma yang lain, seperti judi, minuman keras atau obat-obat terlarang, mencuri dan korupsi. Yang pantas dan yang tidak pantas menjadi sangat kabur tergantung pada masyarakat mana hal itu ditanyakan.Menjadi hal yang sangat penting diperhatikan adalah bagaimana kita mendidik generasi remaja bangsa ini dan dalam lingkungan yang bagaimana? Agar bisa tumbuh menjadi remaja yang brilian bukan delinkuen.

\section{Strategi Pendidikan Agama Islam Integral Progresif Fungsional}

Degradasi moral ataupun kadang disebut sebagai kenakalan remaja (juvenile delinquency), bukanlah murni kesalahan remaja secara sendiri. Mereka membangun dirinya dalam konteks lingkungan masing-masing yang bisa saja menstimuli menguatkan, bahkan mendorongnya dalam mencapai jati dirinya. Ada yang berhasil namun juga tidak jarang ada yang gagal.

Melihat sebab-sebab anak mengalami degradasi moral di era global sehingga cenderung jahat ternyata bermacam-macam, maka jika diatasi dari satu sisi saja akan menjadi kurang maksimal. Penanganan secara psikologis dengan pendekatan ilmu psikologi yang memang dibangun dari pengalaman dan analisa sosial, memang tidak salah, namun jika dijadikan sebagai satu-satunya, maka sangat besar kemungkinan tidak menyelesaikan masalah secara tuntas disebabkan karena perbedaan epistemologi ilmunya itu sendiri. ${ }^{14}$ Misalkan penanganan masalah remaja yang

${ }^{13}$ Al-Mighwar, Psikologi Remaja ..., hlm,144-145.

${ }^{14}$ Perbedaan epistemologi/ bangunan ilmu Islam dan 'barat' sudah bukan rahasia lagi bahkan keduanya secara ontologis terlibat dalam konflik yang berkepanjangan dari masalah politik, ekonomi, budaya yang berakakar dari peradaban Yudeo Kristiani Barat. Lihat Samuel P. Huntington, 2000, The Clash of Civilization and The Remaking of World Order, Terj. M.Sadat Ismail, Benturan Antar Peradaban dan Masa Depan Politik Dunia, (Yogyakarta: Penerbit Qalam, 1996), hlm. 390-415. 
beragama, namun didasarkan pada psikologi Sigmund Freud ataupun William James atau Anton P. Boisen yang jelas-jelas mereka menganggap negatif mengenai agama. James menganggap para nabi dan orang orang suci memiliki perasaan yang berlebihlebihan, melankolis, mengidap halusinasi dan delusi yang menyesatkan, mendengar atau melihat sesuatu yang khayali; Freud menganggap agama sebagai gejala neurosis obsesi yang universal; sedangkan Boisen menganggap bahwa agar orang bisa menghayati agama degan baik, dia harus menderita sakit jiwa terlebih Dahulu atau tahap Schizophrenia. ${ }^{15}$ Cara penanganan psikologis inilah yang kadang secara asumsi dasar berbeda dengan penanganan secara agama.

Pencegahan kenakalan remaja secara umum dapat dilakukan dengan berbagai cara baik moralitas maupun abolisionalistis. Cara moralitas menekankan pada upaya pembentukan dan pembinaan moral dan mental remaja, yang dapat dilakukan melalui penyuluhan kesadaran hukum bagi anak dan remaja, penanaman rasa tanggung jawab sosial, penanaman kesadaran beragama dan penyuluhan tentang sebab-musabab kenakalan remaja. Cara abolisionalitis dalam pencegahan kenakalan remaja dilakukan dengan mengurangi sebab-sebab yang mendorong anak remaja melakukan perbuatan delinkuen. Selain itu upaya pencegahan kenakalan remaja juga dapat dilakukan dengan cara berusaha mengerti pribadi anak dan minatnya serta memberikan cinta kasih yang simpatik.

Lebih dari itu sangat diperlukan untuk dapat mendekati persoalan degradasi moral remaja secara integral. Bahwa persoalan degradasi ini tidak lepas dari arus globalisasi, kapitalisasi dan pembentukan masyarakat industri dengan membawa dampak pada kehidupan sosial dan budaya masyarakat dunia, dan akar dari semua itu adalah paham materialisme. Semua keberhasilan, diukur dari kesanggupannya mengumpulkan materi dan bersenangsenang dengannya.

Berbeda dengan moralitas sosial yang mengalami pergeseran karena paham materialisme dan kapitalisme, aturan pokok moralitas pendidikan Islam tidak akan mengalami pergeseran walaupun zaman globalisasi teknologi terus berkembang. Aturan dan dalil-

\footnotetext{
${ }^{15}$ Kartini kartono dan Jenny Andari, Hygiene Mental dan Kesehatan Mental dalam Islam, (Bandung: Mandar Maju, 1989), hlm. 299.
} 
nya tetap, dengan prinsip bahwa Islam akan tegak dengan dibangunnya lima hal dalam rangka menghargai dan melindungi kehidupan manusia ${ }^{16}$ yaitu syahadat, salat, zakat, puasa bulan ramadan dan haji. Suatu yang haram juga tetap yaitu musyrik, zina, minum-minuman keras dengan segala bentuknya, mencuri, membunuh dan kafir/murtad dengan segala bentuknya. Suatu yang sudah tidak bisa ditawar lagi. Yang boleh berubah hanyalah metode menyampaikannya dengan menggunakan teknologi ataupun dengan pendekatan-pendekatan pembelajaran yang terbaru misalnya pembelajaran aktif ataupun kontekstual. Isi pesan Islam sebagai ruh spiritualitas tidak boleh redup apalagi berubah. Namun disini lebih tepat untuk mengemas pendidikan Islam dengan suatu strategi ${ }^{17}$ pembelajaran yang diajarkan pada remaja di era global ini dengan istiah integral progresif dan fungsional.

Integral, remaja perlu dikenalkan pemahaman pendidikan Islam secara menyeluruh/integral tentang hubungan dengan Allah swt., (tauhid), hubungan dengan sesama manusia yang meliputi kesalehan pribadi dan masyarakat secara adil serta hubungan manusia dengan alam semesta sebagai khalifatullah. Progresif, bersama Islam, remaja diajak untuk merasakan meraih kesuksesan, kemenangan, menyelesaikan masalah dan menemukan arti kehidupan. Remaja perlu dikenalkan progresifitas dan dinamisasi Islam yang pernah mampu mendorong dan memotifasi dan membentuk mental berbagai generasi dan merubah dirinya dari yang terjajah menjadi pribadi yang merdeka, dari lemah menjadi kuat, dari kebingungan menjadi menuju kepastian, dari inferior menjadi superior dan fungsional, remaja sangat membutuhkan pemahaman-pemahaman keagamaan yang mencerahkan dan mampu membimbingnya dalam menghadapi persoalan-persoalan yang dihadapi, memberi solusi dan mengarahkan pembentukan jati diri sebagai generasi yang tangguh dan percaya diri.

Pendidikan Islam Integral Progresif dan Fungsional dapat dikenalkan kepada para remaja dalam bentuk pembimbingan pro-

\footnotetext{
${ }^{16}$ Nurcholish Madjid, Islam Doktrin dan Peradaban, (Jakarta: Yayasan Wakaf Paramadina, 1992), hlm. 2.

${ }^{17}$ Kata strategi berasal dari bahasa Inggris 'strategy'atau bahasa Yunani 'Strategia' dari istilah militer yang keudian dipahami sebagai usaha untuk mendapatkan posisi yang menguntungkan dengan tujuan untuk mencapai kemenangan. Lihat: Djamaluddin Darwis, Dinamika Pendidikan Islam, Sejarah, Ragam dan Kelembagaan, (Semarang: RaSAIL, 2010), hlm. 87.
} 
blem solving dalam menghadapi persoalan diri dan masyarakatnya. Memberikan penyadaran siapa dirinya, siapa keluarganya, siapa temannya dan siapakah masyarakatnya dalam perspektif Islam yang progresif.

\section{Pendidikan Kepribadian}

Spiritualitas: mengajak untuk bersikap berserah diri (berIslam) kepada Allah swt., dengan segala konsekuensinya, menyadari dan bersikap bahwa Allah swt., sebagai sumber kehidupan dan kembalinya kehidupan, sumber kekuatan yang melindungi, sumber kejayaan yang sesungguhnya dalam bentuk mujahadah, ijtihad dan taqarrub. Hal ini akan dapat menghilangkan rasa takut dari ancaman siapa sajadan menghilangkan keraguan yang biasa muncul pada masa remaja.

a. Fisik: membentuk kesadaran remaja dan perilaku dalam solusi praktis untuk menyelesaikan persoalannya bahwa orientasi perbuatan yang membanggakan bukan padarupa dan fisik materiil tetapi lebih berorientasi pada hati dan perbuatanmu. Memberi kesadaran solusi menahan gejolak remaja dengan berpuasa.

b. Psikis: memberi kesadaran mengendalikan diri sebagai kekuatan dan kunci sukses remaja.

2. Pendidikan keluarga, remaja sangat membutuhkan untuk dikenalkan dengan kondisi keluarga yang menjaga diri dari api neraka, ataupun merasakan kenyamananya, kebahagiaanya dan ketenteramannya.

3. Pendidikan dalam lingkungan sekolah. Remaja sangat membutuhkan sekolah yang menjunjung tinggi keunggulan budi pekerti dalam praktik keseharian, akhlakul karimah yang tidak hanya berkompetisi dalam hal materiil namun menghargai kepribadian yang luhur.

4. Pendidikan dalam sosial masyarakat. Remaja perlu selalu dibimbing untuk mampu merasakan bedanya masyarakat yang baik yang diridhai oleh Allah dengan pola masyarakat yang jauh dari nilai-nilai kebaikan. Sehingga remaja akan dapat memilih dan merasa nyaman hidup dengan masyarakat yang secara moralitas baik dan akan merasa tidak nyaman hidup di tengah masyarakat yang moralitasnya rusak. 


\section{E. Penutup}

Dengan menyadari peran dan posisinya masing-masing dalam kehidupan ini, sangat bisa menjadikan remaja untuk menyeleksi mana yang baik dan mana yang buruk dari norma-norma globalisasi dan dapat membentengi diri dari norma negatif globalisasi yang cenderung menghancurkan kemanusiaan, serta dengan mengenalkan Islam yang integral, progresif dan fungsional kepada para remaja diharapkan mereka akan dapat melalui masa remajanya dengan penuh Prestasi dan keluhuran budi berdasar akhlakul karimah dan jauh dari dekadensi moral.

\section{Kepustakaan}

Ahimsa-Putra, Shri, Strukturalisme Levi-Strauss, Mitos dan Karya Sastra, Yogyakarta: Galang Press, 2001.

Al-Mighwar, Muhammad, Psikologi Remaja, Petunjuk Bagi Guru dan Orang Tua, Bandung: Pustaka Sia, 2011.

Arief, Armai, Tantangan Pendidikan di Era Global, Artikel, Jakarta: FAI-UMJ, 2010.

Aziz, Abdul, Esai-Esai Sosiologi Agama, Jakarta: Diva Pustaka, 2006.

Darwis, Djamaluddin, Dinamika Pendidikan Islam, Sejarah, Ragam dan Kelembagaan, Semarang: RaSAIL (Ranah IlmuIlmu Sosial Keagamaan dan Interdisiplier, 2010.

Daradjat, Zakiah, Ilmu Jiwa Agama, Jakarta: Bulan Bintag, 1979.

Jenggis P, Akhmad, 10 Isu Global di Dunia Islam, NFP Yogyakarta: Publishing, 2012.

Kartono, Kartini dan Jenny Andari, Hygiene Mental dan Kesehatan Mental dalam Islam, Bandung: Mandar Maju, 1989.

Kartini Kartono, Patologi Sosial 2, Kenakalan Remaja, Jakarta: Raja Grafindo Persada, 2013.

Madjid, Nurcholish, Islam Doktrin dan Peradaban, Jakarta: Yayasan Wakaf Paramadina, 1992.

Nurihsan, Achmad Juntika dan H. Mubiar Agustin, Dinamika Perkembangan Anak \& Remaja, Tinjauan Psikologi, Pendidikan, dan Bimbingan, Bandung: Refika Aditama, 2013. 
Huntington, Samuel P., The Clash of Civilization and TheRemaking of World Order,1996. Terj. M.Sadat Ismail, Benturan Antar Peradaban dan Masa Depan Politik Dunia, Yogyakarta: Qalam, 2000.

Suyanto, dan Djihad Hisyam, Refleksi dan Reformasi Pendidikan di Indonesia Memasuki Milenium III, Yogyakarta: Adicita Karya Nusa, 2000.

Yin-wah Chu: Sociology, Global Culture: hegemony or plurality?,www.edb.gov.hk/FileManager/TC/Content_5205/chuyw_ global_culture_text.ppt

http://aurabianglala.blogspot.com/2012/12/periode-emas-dan-kritis-pada-anak.html

http://hukum.unmuhjember.ac.id/index.php/13-berita/11-kenakalan-remaja.

http://hukum.unmuhjember.ac.id/index.php/13-berita/11-kenakalan-remaja.

http://www.m-edukasi.web.id/2013/08/budaya-dan-Karakterwajah-kurikulum-baru.html, Yanuri Natalia Sunata Copyright www.m-edukasi.web.id Media Pendidikan Indonesia. 
